Research Report No. 3/2005

\title{
Corporate Governance and Law Reform in Japan: From the Lost Decade to the End of History?
}

Luke R. Nottage

Leon T.Wolff

Follow this and additional works at: http:/ / digitalcommons.osgoode.yorku.ca/clpe

\section{Recommended Citation}

Nottage, Luke R. and Wolff, Leon T., "Corporate Governance and Law Reform in Japan: From the Lost Decade to the End of History?" (2005). Comparative Research in Law \& Political Economy. Research Paper No. 3/2005.

http://digitalcommons.osgoode.yorku.ca/clpe/171 
Comparative Research in Law and Political Economy

CLPE

Research Paper No. 3/2005

University of Sydney

Sydney Law School

Legal Studies Research Paper No. 06/14

\title{
Corporate Governance and Law Reform in Japan: From the Lost Decade to the End of History?
}

\author{
Luke R. Nottage \\ University of Sydney - Faculty of Law \& Australian Network for Japanese Law \\ Leon T. Wolff \\ University of New South Wales - Faculty of Law
}

2005

This paper can be downloaded without charge from the Social Science Research Network Electronic Paper Collection at:

http://ssrn.com/abstract=830005 
CLPE Research Paper 3/2005

Vol. 01 No. 01 (2005)

Luke Nottage and Leon Wolff

\title{
CORPORATE GOVERNANCE AND LAW REFORM IN JAPAN: From THE LOST DECADE TO THE END OF HISTORY?
}

\begin{abstract}
Japan is in the midst of massive law reform. Mired in ongoing recession since the early 1990s, Japan has been implementing a new regulatory blueprint to kickstart a sluggish economy through structural change. A key element to this reform process is a rethink of corporate governance and its stakeholder relations. With a patchwork of legislative initiatives in areas as diverse as corporate law, finance, labour relations, consumer protection, public administration and civil justice, this new model is beginning to take shape.
\end{abstract}

But to what extent does this model represent a break from the past? Some commentators are breathlessly predicting the "Americanisation" of Japanese law. They see the triumph of Western-style capitalism - the "End of History", to borrow the words of Francis Fukuyama - with its emphasis on market-based, arms-length transactions. Others are more cautious, advancing the view that there new reforms are merely "creative twists" on what is a uniquely (although slowly evolving) strand of Japanese capitalism.

This paper takes issue with both interpretations. It argues that the new reforms merely follow Japan's long tradition of 'adopting and adapting' foreign models to suit domestic purposes. They are neither the wholesale importation of "Anglo-Saxon" regulatory principles nor a thin veneer over a 'uniquely unique' form of Confucian cultural capitalism. Rather, they represent a specific and largely political solution (conservative reformism) to a current economic problem (recession). 
The larger themes of this paper are 'change' and 'continuity'. 'Change' suggests evolution to something identifiable; 'continuity' suggests adhering to an existing state of affairs. Although notionally opposites, 'change' and 'continuity' have something in common - they both suggest some form of predictability and coherence in regulatory reform. Our paper, by contrast, submits that Japanese corporate governance reform or, indeed, law reform more generally in Japan, is contextspecific, multi-layered (with different dimensions not necessarily pulling all in the same direction - for example, in relations with key outside suppliers), and therefore more random or 'chaotic'.

Author Contact: Dr. Luke Nottage and Leon Wolff Co-Directors, Australian Network for Japanese Law

Email: luken@law.usyd.edu.au; leon.wolff@unsw.edu.au 


\title{
CORPORATE GOVERNANCE AND LAW REFORM IN JAPAN: FroM THE LOST DECADE TO THE END OF HISTORY?^
}

\author{
Luke Nottage $\uplus$ Leon Wolff
}

\section{From THE LOST DECADE TO THE END OF HISTORY?}

Much has been made of Japan's 'lost decade'. With economic stagnation, financial crisis and record corporate insolvencies during the 1990s, Japan's once all-mighty economic machine appears to have lost its way. But sluggishness in economic performance stands in contrast to an enormous burst of activity in law reform. On a scale comparable to the massive legal innovation when Japan re-opened to the world in the Meiji Restoration from 1868 and the democraticisation of constitutional and economic law during the Allied Occupation from 1945 to 1952, Japan is embarking on a 'third wave' of legal and regulatory reform. The primary driver of the reform movement is growing desperation to regain economic momentum. A guiding theme is dismantling $e x$ ante regulation of businesses primarily by public authorities and introducing more indirect means of ex post control by empowering private entities with private or corporate law remedies. ${ }^{1}$

\footnotetext{
* The core of this chapter builds heavily on Nottage (2001b) and its Working Paper version available through http://www.iue.it/PUB/WorkingPapers.shtml, extensively updated and supplemented by research drawing on the authors' work as contributing editors for the Japan tab of the CCH Doing Business in Asia looseleaf/CD-ROM service (Nottage and Wolff 2000-3). Additional references and data can be found in those works. In addition to those acknowledged therein, we acknowledge valuable feedback and information from Phil Jamieson of Nagashima Ohno Tsunematsu and participants in the 2004 Corporate Law Teachers' Association Conference (8-11 February, Australian National University). All internet references were available at the URLs given as of 1 February 2004.

${ }^{1}$ However, Schaede $(2000,2003)$ argues that another theme of the reform movement is that public regulation by bureaucracies is giving way to self-
} 
What should be made of these legal developments? An emerging line of analysis is that Japanese law is in the process of 'Americanisation'. According to Daniel Keleman and Eric Sibbitt (2002), for example, the Americanisation of Japanese law is evident from accelerating economic liberalisation, political fragmentation, and greater 'legalisation' in everyday life in Japan since the 'lost decade'. Curtis Milhaupt (2003), too, submits that, despite some 'stickiness' in traditional corporate governance norms, Japanese corporate law is taking on more visibly American shape. The core claim is that American law represent the global standard in corporate regulation, and that Japan is inching its way inexorably - towards adopting this standard.

This thesis of the Americanisation of Japanese law recalls Francis Fukuyama's (1992) famous prediction about the 'end of history' that U.S.-style political democracy and market-based economic ordering would triumph in the post-communist order. The attraction of Fukuyama's ideas has not been limited to political scientists, economists, and business leaders. They have also found traction in the legal academy. For example, Henry Hansmann and Reiner Kraakman (2001), law professors from Yale and Harvard respectively, prophesised the 'end of history for corporate law'. They write in support of continued and accelerating convergence on a shareholder-oriented model of corporate governance, involving extensive use of market-based control mechanisms to guide corporate activity and corporate law. Paralleling Fukuyama, Hansmann and Kraakman (2001: 443-9) emphasize the 'failure of alternative models': the 'manager-oriented model' (popular in the US until the 1960s), the 'labour-oriented model' (entrenched primarily in Germany), the 'state-oriented model' (perceived as dominating post-war France and Japan), and 'stakeholder models' (seen as mere variants on older manager- or labour-oriented models). They then argue that competitive pressures will cause

regulation by private industry associations. Less globally competitive industries are tending to adopt self-regulation with more risk of anti-competitive effects. 
convergence on the shareholder-oriented model and highlight the rise of the shareholder class worldwide, conceding, however, that change has so far occurred at the level more of corporate practices than of formal legal rules. Other commentators have taken this a step further, in the related area of competition law, implying 'the end of anti-trust history'.

This triumphalism - that American law represents both the pinnacle of legal achievement and the global standard to which other legal systems aspire to achieve - has attracted many critics. Some, for example, argue that US anti-trust law and practice has a bifurcated tradition, with one strand closer to the European Union's model of regulation more through administrative agencies than private enforcement for the primary benefit of dispersed consumers (Perez 2002). Others contend that a 'general process of Americanisation in legal thinking' - or 'imperial $\mathrm{law}^{\prime}$ - is 'a dominant layer in world-wide legal systems', but one underpinned by 'a spectacular process of exaggeration, aimed at building consent for the purpose of hegemonic domination' (Mattei 2003: $383)$, and encountering resistance in continental Europe. Moreover, doubts have been raised about the straightforward Americanisation of corporate law. For example, von Nessen (1999, 2003) notes that the wave of reforms to Australian corporate law since the late 1990s, although inspired by some specific US developments and more general concepts, were filtered through the lens of an English law tradition. Further, Australian law reforms encounter local circumstances (see generally Cheffins 2002). Full-scale 'Americanisation of Japanese law' seems equally, if not more, implausible. Indeed, aspects of Japanese private law may be undergoing a new round of 'Europeanisation' and more idiosyncratic globalisation (Nottage 2004).

This chapter aims to assess claims of Americanisation of Japanese law by critically examining the recent raft of reforms to Japanese corporate governance. At first blush, there is much to suggest Americanisation. First, corporate governance has indeed shifted towards a more shareholder-oriented model: the law now provides for more direct control potential for shareholders to monitor 
opportunistic managers. Second, certain non-shareholders (especially creditors) are empowered with greater arms' length control mechanisms. However, the degree and direction of the transformations vary according to the stakeholder (Nottage 2001b). For example, direct controls by employees, still an important stakeholder in Japanese companies, are declining more slowly. Further, suppliers, consumers, government authorities and even NGOs appear still more prepared to interact with companies and managers on the basis of trust, rather than designing control mechanisms on the assumption that there will always be opportunism or deviance which needs to be guarded against /cf also Fukuyama 1996). In short, Japanese corporate governance and indeed its entire system of capitalism - is converging to a degree on the US model, but at divergent rates seemingly related to resilient underlying norms and philosophies (see also Sarra and Nakahigashi 2002). It may be that this is a temporary situation, on the way to a more consistent end of history à la américaine. But it seems more likely that this is more or less a new equilibrium, as seems to have been reached also in German corporate law reform (du Plessis 2004). The picture in Japan is clouded by complexity within economic ordering as well as greater competition in politics (cf Dore 2000). This more 'chaotic' outcome, combining change with elements of continuity, may be difficult for economists, political scientists and lawyers to handle; but should be more readily appreciated by practitioners and analysts of business management, where messy practical realities are valued as well as elegant theory.

\section{ReAligning StAKeholders In JAPANeSE CoRporate GOVERNANCE}

This chapter adopts a stakeholder analysis to outline the contours of change and continuity. Although the relationship between managers and shareholders is central to conceptualising the operation of corporate entities, other stakeholders are also 
influential, including creditors, employees or suppliers, and even local residents or government authorities. ${ }^{2}$

A stakeholder analysis focuses attention on major problems common to all stakeholder relationship. An important problem is incomplete information. If all shared full information, shareholders or creditors, for instance, would not have to worry about managers wasting their money. Yet in the real world, incomplete information gives rise to the dual problems of 'adverse selection' ('hidden information', resulting for example in creditors accepting to lend money to what turn out to be generally high-risk firms) and 'moral hazard' ('hidden action', for example managers investing loaned funds into excessively high risk projects). These difficulties are compounded by others: (i) the inability to write contracts for the stakeholder relationships which expressly provide for all possible contingencies, because of the limits in foreseeing future scenarios (Hoshi 1998: 849-850); and (ii) the inability to perfectly enforce those contracts. These definitions of adverse selection and moral hazard highlight underlying problems of opportunism and bounded rationality (Williamson 1996). They can be usefully developed to uncover and structure empirical data concerning relations involving managers and shareholders (II.1 below), creditors of the firm (Part II.2), and employees (Part II.3). The overall picture is one of (i) significant rapprochement of manager and shareholder interests and the (ii) elimination of cartel-like regulation of banks and other financial institutions; but (iii) less obvious or more gradual pressures reshaping employment relations.

Yet raw opportunism may not be the only force at work (Part II.4). A stakeholder analysis can also reveal robust patterns of cooperative relations among participants. Consider, for example, the automobile industry in post-war Japan and, subsequently in

\footnotetext{
${ }^{2}$ Cf also Kester 1996; Ballon and Honda 2000. Tsuru (1999: 3) cautions that such a broad definition of corporate governance may risk analytic looseness (see also Cioffi 2000. But cf Aoki 2003.
} 
the U.S. Where an expanding group of participants engage in quite radical information gathering and sharing among one another, they entrenching trust, leading to the emergence of novel forms of corporate governance (Helper, McDuffie and Sabel 2000). Although the overall trend is towards arms' length relations in Japan, cooperation is still in evidence. In particular, there is evidence of new patterns of cooperation at the level of the Japanese state and civil society (Schwartz and Pharr eds 2003), increasingly important stakeholders in corporate organizations.

\section{A. SHAReHolders Becoming Primary StakeHolders}

The separation of ownership from control in public listed companies, ${ }^{3}$ leading to the emergence of a distinct managerial class with interests no longer necessarily aligned with shareholders, has become an agreed starting point for analysing corporate governance since being highlighted in the US by Berle and Means (1991 [originally 1932]). Particularly since Japan's US-led Occupation following World War II, successive reforms to Japanese corporate law have often been directed precisely at protecting shareholders' rights (Hayakawa 1997).

In fact, from the perspective of agency theory, two categories of constraints are available to shareholders to counter particularly the informational advantage held by managers. The first is 'control oriented'. The shareholders monitor management behaviour, often delegating this to a Board of Directors whom they elect; and they intervene if necessary, for example by a proxy vote fight, to replace directors and hence managers. However, the costs involved in this

\footnotetext{
${ }^{3}$ There are about 9,000 such companies in Japan (Kanda 1998 contains useful further background corporate data), including about 6330 with sufficient capital for listing (Yasui 1999: 3). Closely held companies, in which shareholders typically remain managers or are closely related to them, offer different avenues for opportunistic behaviour. Despite their aggregate importance in the Japanese economy, these companies' problems have not generated the same degree of law reform and discussion in recent years (see for example Shishido 1990). This chapter therefore only mentions them in passing (at Part II.2).
} 
system usually make it more attractive to large shareholders with good management skills themselves. A second system available to shareholders, 'arm's length' control, is more passive. The shareholders do not actively intervene in management. However, they take action when dissatisfied with managers, especially by selling shares, which may lower share prices and for example encourage hostile takeovers. Alternatively, indirect control can be promoted through institutions better aligning the interests of managers with shareholders, for example through high-powered incentive methods such as very profit-sensitive bonuses or stock options (Hoshi 1998: 851-2). The received wisdom about companies in post-War Japan is that such arm's length controls have been particularly weak.

Openly hostile takeovers have certainly been rare. ${ }^{4}$ In large part, this is due to the development of extensive cross-shareholdings among firms. The main reason for cross-shareholdings emerging remains unclear, although most accounts point to stock market weaknesses soon after World War II, when capital was needed by companies and the threat of takeovers was high. Ironically, crossshareholding also may have developed because Japanese corporate law, influenced by U.S. law, further extended substantive rights to shareholders, yet many of those rights have remained mandatory (Shishido 2000: 211). Japanese managers therefore may have encouraged the development of cross-shareholding as an alternative way to protect their interests. ${ }^{5}$

\footnotetext{
${ }^{4}$ Nonetheless, there have been several major hostile takeover battles since the late 1990s. Tokumoto (2001) discusses four that resulted in court judgments, and criticises Japanese judges for too readily thwarting takeovers by allowing incumbent directors to issues shares to third parties (ostensibly due to a need to raise capital). Another well-publicised case of 'greenmail' involved a US investor, T Boone Pickens, between 1989 and 1991 (Reich 2001).

${ }^{5}$ See also Takahashi 1997: 232. Managers in the US and elsewhere have been able to invoke other techniques more recently, through tailoring their corporate constitutions etc (for example 'poison pills' whereby a debenture etc must be issued if an investor purchases more than a set percentage of shares, or
} 
Nonetheless, some arm's length control continued to be exercised through ostensibly 'friendly' takeovers or mergers. These often occurred in the context of poor performance, reflected in weak share prices; and strong correlations have been found between share price weakness and resignations of managers (Kaplan and Ramseyer 1996). Thus, while managers are not replaced by those taking over firms, as in hostile bids, they retire 'voluntarily'. Shishido (2000: 216) provides one important causal explanation for this pattern: Japanese firms who perform badly on the sharemarket find it difficult to raise equity finance, and that makes it more difficult to obtain debt finance from banks. Such pressures have grown as Japan has mired itself in recession. Conversely, he notes some recent evidence that pressures from the Japanese share market already are forcing some firms to restructure their labor relations, and then signaling satisfaction with that management response in the form of higher share prices (idem, fn 112). Overall, moreover, aggregate cross-shareholding in publically traded shares has declined significantly since the stock market collapse and burst of Japan's 'bubble' economy in the early 1990s. ${ }^{6}$ Further, building from this competing tradition of such indirect control mechanisms and more recent changes to Japan's socio-economic environment, a few 'norm entrepreneurs' are now openly embarking on hostile takeover activity (Milhaupt 2001: 21-23). A growing body of empirical research shows how significant change can be achieved in Japan by law reform legitimizing new social

arrangements to limit to voting rights to a minority percentage even if the investor obtains more than that percentage of shares). The liberalisation of stock option schemes in Japan may open the way to such stratagems, but this possibility has not been openly discussed much (Kozuka 2003). It probably awaits a more comprehensive move towards pro-active commercial lawyering linked to major reforms now underway in the Japanese legal profession (Kobayashi 2003).

${ }^{6}$ Takahashi 1997: 233-4. Indeed the pace seems to be accelerating (for example Shishido 2000: 226, Table 6). As well as banks' immediate need to cash-up, this trend may be underpinned by a more forward-looking appreciation that main bank shareholdings have tended to be in firms with smaller prospects for growth (evidenced by Hori and Osano 2002). 
norms, or reinforcing selected existing ones. ${ }^{7}$ With takeovers, a quite amenable legal framework has long been in place, in terms of formal substantive law provisions, and that may make it even easier for social norms to be reformulated and take root. Milhaupt and West (2001) argue that this process is already underway, underpinned by takeovers' potential to promote efficient diversity in corporate organisations.

More directly aligning the interests of managers and shareholders has met with more mixed success. Stock option schemes have been progressively liberalized since the mid-1990s, and in 2002 the Tokyo District Court adopted an interpretation favourable to the taxpayer. However, this has been appealed by the government, and tax legislation continues to change. Also, the stock options involved in this litigation were issued by foreign companies. ${ }^{8}$ Still, stock option schemes appear to have steadily gained in popularity, with 800 Japanese companies reportedly having them by 2000 (Ahmadjian 2003: 222). However, such schemes may be subjected to increasing scrutiny if and when committees for remunerating managers are established (as discussed below) and Japan's sharemarket revives significantly, even though executive remuneration in Japan has remained comparatively low. Problems of excessive remuneration have been exposed in countries like the US and Australia following spectacular corporate collapses in recent years (Clarke et al 2003), highlighting the need for transparency and some limits in setting remuneration packages to provide incentives to managers to work in shareholders' interests (Hill and Yablon 2003). Similar issues arise with bonuses and other remuneration for managers which are tightly tied to performance. Although these have not been common in post-War Japan either, performance-linked employment is steadily replacing seniority-

\footnotetext{
${ }^{7}$ For example West 1997, Feldman 2001, Nottage 2004.

${ }^{8}$ Watanabe 2004, discussing mainly the Microsoft case, decided on 26 November 2002 and reported in 1106 Hanrei Taimuzu, p. 28. He notes that on the same day, the Tokyo District Court decided a quite similar case involving Compaq.
} 
based 'life-long' employment even in the larger blue-chip companies (Shibata 2002; and generally Part II.3 below). Compounding this shift, whereas shareholders may have achieved some indirect arm's length control over managers because of the latter's 'career concerns' - tying their reputation to company performance (Tsuru 1999: 5) - Japan's protracted economic stagnation appears to be underpinning the slow emergence of alternative mechanisms.

At the same time, control-oriented mechanisms have been expanding too. To be sure, as cross-shareholdings have declined, the potential for such shareholders to exercise direct control over managers in the other companies has been reduced. However, such control was limited anyway, due to relatively small blocs of shares being held by rather loosely affiliated groups, perhaps reinforced by a norm against active intervention which made sense during Japan's era of strong economic growth. A much more important direct check on managers has been exercised by 'main banks', often holding an even smaller shareholding in the client firm (statutorily limited to 5 percent), but able to monitor its performance by providing a broad array of services and to intervene if necessary (Milhaupt 2002). As mentioned below (Part II.2), however, the main bank system has come under even greater pressure than cross-shareholdings generally, due to crises and deregulation in financial markets especially since the late 1990s.

Nonetheless, at least partially offsetting these two trends, the potential for more control-oriented checks on managers has been expanded by the growing importance of institutional investors in Japan, as elsewhere. Japan's pension funds and the like now find themselves in dire financial straits, with no guarantees - even implicit - that the government will be interested or able to bail them out, given its own crisis in preparing for a rapidly ageing population (Morgan 2001). Even more significant, at least to the mind of many Japanese managers in recent years, is the growing 'presence' of foreign pension funds demanding better results and transparency from the firms they invest in (Ahmadjian 2003: 2323 ). In the shadow of major changes in accounting standards, 'return 
on equity' has become a more pervasive concern even among firms with no or limited foreign investment, as evidenced by the recent popularity of share buy-backs. ${ }^{9}$

Even smaller investors, including a now strong proportion from abroad in the wake of Japan's stockmarket downturn over the 1990s, can also exert direct control through actual or potential derivative actions against managers who fail to act in the best interests of the company, including the interests of shareholders. Following a reduction in filing fees in 1993, the numbers of derivative lawsuits have grown rapidly. Activist lawyers and groups have emerged, taking advantage of the new institutional realities and promoting another shift in norms about the 'proper' role for shareholder interests, illustrated and cemented by a remarkable victory in 2000 against Daiwa Bank executives. Concerns on the part of mangers about personal liability in such litigation led in 2002 to further law reforms to limit somewhat the scope or effects of derivative actions (Black and Cheffins 2003: 83). However, the legal and socio-economic framework for derivative actions remains very different from that present at the start of Japan's lost decade (West 2001b).

Some skeptics suggest that the restrictions enacted in 2002 were primarily a 'defensive' reaction promoted by managers, as indeed

\footnotetext{
${ }^{9}$ Amendments to the Commercial Code, coming into operation on 1 October 2001, removed the restrictions on share buy-back schemes. Under the new provisions, share buy-backs are permitted provided the repurchase is authorized by shareholders in advance at the annual general meeting and the repurchase is funded out of distributable profits. Share buybacks give shareholders a greater share of company profits. This is because share repurchases transfer wealth from selling shareholders to the residual shareholders, and increases earnings per share. Major Japanese companies (spearheaded for example by Sony, Matsushita, NTT, Honda and Toyota) are increasingly using these new powers to protect the value of shareholders' equity investments. According to a report in the Japan Times (20 May 2002), Japanese companies listed on the first section of the Tokyo Stock Exchange have announced share buy-back plans involving 4.2 trillion yen worth of shares, double that which was repurchased in all of fiscal year 2001 .
} 
were reductions in the large numbers of managers traditionally elected to Boards of Directors in Japan. They emphasized how only remaining Board members, not the new category of 'executive officers', were left at risk of derivative actions. However, this shift to smaller boards seems to have begun in the late 1990s (Moerke 2003). Further, downsizing was initiated primarily by Sony, a wellmanaged company with high foreign ownership. It also committed itself to including independent directors on the downsized Board, emphasizing its role as a monitor (especially on behalf of shareholders) over the activities of executive officers and other line managers. Sony's new system therefore seems better explained by pressures like those described above, particularly the more or less latent demands of investors, and a realisation that other mechanisms minimizing poor managerial performance were being undermined precisely as Japanese companies were being exposed to ever-greater legal and economic risks.

Further, by June 2001, 35.7 percent of listed companies had already adopted what Puchniak (2003) calls a 'Sony Type Company' model and 24.4 percent of companies were contemplating adopting it. In other words, only 40 percent of companies still seemed wedded to the 'Old Type Company' model, involving a very large Board (including many managers primarily with executive responsibilities), complemented by 'statutory auditors' or 'auditing officers' (kansayaku) supposed to monitor certain activities of the Board. In 2002, the Commercial Code was amended to allow large companies to retain either of these structures, or adopt either what Puchniak terms a 'New Type Company' variant on Sony's original model, or a 'Reformed Old Type Company' model instead further boosting the kansayaku system. As highlighted in Chart 1 below, key differences between the 'Sony Type Company' model and the 'New Type Company' model are that the latter demands at least two outside directors, key decisions (for example on remuneration) must be made by committees involving some them, and officers are also open to shareholder derivative suits. 
Chart 1: Japanese Corporate Governance Models After the 2002 REFORM

\begin{tabular}{|c|c|c|c|c|}
\hline & $\begin{array}{l}\text { Old Type } \\
\text { Company }\end{array}$ & $\begin{array}{l}\text { Reformed Old } \\
\text { Type } \\
\text { Company }\end{array}$ & $\begin{array}{l}\text { Sony Type } \\
\text { Company }\end{array}$ & $\begin{array}{l}\text { New Type } \\
\text { Company }\end{array}$ \\
\hline $\begin{array}{l}\text { Number of } \\
\text { outside } \\
\text { directors }\end{array}$ & $\begin{array}{l}\text { No requirement } \\
\text { for outside } \\
\text { directors } \\
\text { according to law } \\
\text { No outside } \\
\text { directors in } \\
\text { practice }\end{array}$ & $\begin{array}{l}\text { One outside } \\
\text { director } \\
\text { required by } \\
\text { law }\end{array}$ & $\begin{array}{l}\text { No outside } \\
\text { directors } \\
\text { required by law } \\
2 \text { to } 3 \text { outside } \\
\text { directors in } \\
\text { practice }\end{array}$ & $\begin{array}{l}2 \text { outside } \\
\text { directors } \\
\text { required by } \\
\text { law }\end{array}$ \\
\hline $\begin{array}{l}\text { Number of } \\
\text { directors }\end{array}$ & $\begin{array}{l}3 \text { directors } \\
\text { required by law } \\
20 \text { to } 40 \\
\text { directors in } \\
\text { practice }\end{array}$ & $\begin{array}{l}\text { At least } 10 \\
\text { directors } \\
\text { required by } \\
\text { law }\end{array}$ & $\begin{array}{l}3 \text { directors } \\
\text { required by law } \\
10 \text { directors in } \\
\text { practice }\end{array}$ & $\begin{array}{l}3 \text { directors } \\
\text { required by } \\
\text { law }\end{array}$ \\
\hline $\begin{array}{l}\text { Targets of } \\
\text { Shareholder } \\
\text { Class-Action } \\
\text { Law Suits }\end{array}$ & $\begin{array}{l}\text { Directors and } \\
\text { Statutory } \\
\text { Auditors }\end{array}$ & $\begin{array}{l}\text { Directors and } \\
\text { Statutory } \\
\text { Auditors }\end{array}$ & $\begin{array}{l}\text { Directors and } \\
\text { Statutory } \\
\text { Auditors } \\
\text { However, many } \\
\text { of the decision } \\
\text { makers are } \\
\text { officers (shikko } \\
\text { yakuin) but not } \\
\text { subject to } \\
\text { derivative } \\
\text { actions }\end{array}$ & $\begin{array}{l}\text { Directors and } \\
\text { Officers } \\
\text { (shikko yaku) } \\
\text { Officers are } \\
\text { (also) subject } \\
\text { to derivative } \\
\text { actions }\end{array}$ \\
\hline Committees & $\begin{array}{l}\text { No committees } \\
\text { required by law } \\
\text { Managing } \\
\text { committee } \\
\text { composed of a } \\
\text { few senior } \\
\text { directors who } \\
\text { make all } \\
\text { important } \\
\text { decisions in } \\
\text { practice }\end{array}$ & $\begin{array}{l}\text { Managing } \\
\text { committee } \\
\text { required by } \\
\text { law (three or } \\
\text { more } \\
\text { members) } \\
\text { No outside } \\
\text { directors } \\
\text { required on } \\
\text { managing } \\
\text { committee }\end{array}$ & $\begin{array}{l}\text { No committees } \\
\text { required by law } \\
\text { Committee } \\
\text { system with } \\
\text { outside directors } \\
\text { in practice }\end{array}$ & $\begin{array}{l}\text { Nominating, } \\
\text { remuneration } \\
\text { and audit } \\
\text { committee } \\
\text { (three or more } \\
\text { members per } \\
\text { committee, } \\
\text { the majority } \\
\text { with outside } \\
\text { directors) } \\
\text { required by } \\
\text { law }\end{array}$ \\
\hline
\end{tabular}




\begin{tabular}{|c|c|c|c|c|}
\hline $\begin{array}{l}\text { Statutory } \\
\text { auditors } \\
\text { (kansayaku) }\end{array}$ & $\begin{array}{l}4 \text { statutory } \\
\text { auditors required } \\
\text { by law } \\
\text { At least half of } \\
\text { the statutory } \\
\text { auditors are } \\
\text { required by law } \\
\text { to be outsiders }\end{array}$ & $\begin{array}{l}4 \text { statutory } \\
\text { auditors } \\
\text { required by } \\
\text { law } \\
\text { At least half of } \\
\text { the statutory } \\
\text { auditors are } \\
\text { required by } \\
\text { law to be } \\
\text { outsiders }\end{array}$ & $\begin{array}{l}4 \text { statutory } \\
\text { auditors required } \\
\text { by law } \\
\text { At least half of } \\
\text { the statutory } \\
\text { auditors are } \\
\text { required by law } \\
\text { to be outsiders }\end{array}$ & $\begin{array}{l}\text { Statutory } \\
\text { auditors } \\
\text { prohibited by } \\
\text { law }\end{array}$ \\
\hline
\end{tabular}

(Puchniak 2003, emphasis added)

Several criticisms have been directed at this new menu of corporate governance options, in concluding that little real change will eventuate (see generally for example Rodatz 2003). First, the requirement of 'independence' for directors (and indeed kansayaku) is thought not to be strict enough. However, that awaits clarification by the courts, and/or the risk that rules will be further tightened once a firm has sunk costs into transforming itself into a Reformed Old Type Company or especially a New Type Company.

A second criticism is that the reform will not work because companies will not move especially from a Sony Type Company into a New Type Company, because this will expose their executive officers also to shareholder derivative actions (Kashiwagi 2003, p.7). However, the risks for such officers are limited somewhat by the safeguards enacted in 2002. Anyway, many of those who have already gone to the trouble of becoming a Sony Type Company are likely to be firms which are better managed or genuinely want to improve their governance and overall performance.

Third, the reform does not force companies to adopt a particular model; in other words, the reform is 'elective' (Nottage 2003). This criticism tends to be made particularly by US commentators, describing the 'New Type Company' as the US model and the most efficient one. A potential irony here is that at least some Japanese policy-makers are probably being more consistent with 
the ideology of market liberalism generally propounded so vigorously in the US. Ahmadjian (2003: 230) observes that the logic of Japan's Ministry of External Trade and Industry (METI, previously MITI) was that 'the market would eventually decide which form of governance was most effective'. On the other hand, she concedes that METI had initially favoured more the New Type Company model, but leaving open a choice (to move also to a Reformed Old Type Companyl 'was a compromise under pressure from Keidanren ... facing its own internal pressures, both from global firms that wanted to reshape their boards to reflect US practices, and from domestic firms which resisted change'.10 Less invasive pressure on companies to reform their governance structures has also been a hallmark of Anglo-Commonwealth countries, which have also drawn more or less on US features in fashioning the options (Puchniak 2003); and leaving in particular options based on the kansayaku system may reflect an enduring attraction of German corporate law, which moreover has implemented mostly on an optional basis (du Plessis 2004). However, as mentioned in the Conclusions below (Part III), the element of compromise - and its particular style: leaving in place existing structures, and just superimposing reformed structures does appear to represent a 'reformist conservatism' found in other areas of Japanese law and society (Nottage 2001c).

Thus, it is hardly compelling to argue that Japan's 'elective corporate governance reform' does not go far enough yet, at the same time, it already signals a significant step towards 'Americanstyle' corporate governance (Senechal 2003). More interesting are

\footnotetext{
${ }^{10}$ Nippon Keidanren was formed in 2002 by amalgamating two important peak business bodies, Keidanren (Japan Federation of Economic Organisations) and Nikkeiren (Japan Federation of Employers' Associations). The former, in particular, includes larger firms which have increasingly pushed for liberalisation in Japan as they expanded their operations world-wide (Yoshimatsu 2000). The current Chairman of Nippon Keidanren (and Toyota), has been robust in his criticism of the Koizumi administration for not being decisive and innovative enough in carrying out structural reform (Okuda 2003). On changes in METI's stance towards economic reform, see Elder 2003.
} 
prognoses like that of Ahmadjian (2003, p. 231) who argues that this reform illustrates nicely the thesis of 'Japan's managed globalisation' based on 'permeable insulation' (Schaede and Grimes 2003). She predicts the emergence of:

a dual system of governance[:) Globally oriented firms would increase board independence and introduce auditing, nomination and compensation committees, while more domestically focused firms would maintain the kansayaku system and continue to maintain managerial autonomy and insulation from the demands of shareholders.

To some extent this appears to be proving correct, judging from reports of trends in adopting the New Type Company form since the option was implemented from June 2003. However, these are still early days, and a final assessment is further complicated by what is meant by 'globally oriented firms'. Sony quickly became a New Type Company, and indeed went a step further than required by separating out the posts of Board Chairperson and Chief Executive Officer. ${ }^{11}$ The form has also been adopted by large companies particularly in the consumer electronics sector, with less foreign ownership, but certainly exposed to and engaging with highly competitive markets world-wide. However, of the 55 firms which had become New Type Companies by August 2003, several appear distinctly more domestically focused, such as large retailers and smaller banks (Kubori 2003, pp. 4-5). It could be that these firms want to become more 'globally oriented', either by attracting

11 'Revised Commercial Code Introduces US-Style Corporate Governance' 42(5) Japan Labor Bulletin (May 2003), p.2. Kashiwagi (2003, p. 5) sees this sort of step as crucial to the success of New Type Companies, to fracture a practice of Chairpersons (typically also CEOs) electing their successors, despite Nominating Committees in New Type Companies formally being required to have a majority of outside directors. 
foreign investment or expanding into markets abroad, but that is difficult to prove. Another explanation may be that these firms now believe that New Type Companies have more efficient corporate governance, which translates into better economic performance, even primarily in domestic markets. They may also think that this is due to this form being 'American', and discount problems in the US exposed by corporate collapses like Enron's, or believe in the form's efficiency because they have heard of it or its variants being adopted in Anglo-Commonwealth countries or even some in continental Europe (Hill and Yablon 2003). But such 'global' considerations may be minimal or non-existent for most of these firms, filtered out in the recommendations reached by policy-makers like METI, and the mass of media reporting on Japan's now regular corporate law reforms.

In short, even an intensification of more broad-based adoption of the New Type Company form may be better conceptualized as a pragmatic inculcation of more abstract or 'indigenized' expectations about governance and its putative links to economic performance. ${ }^{12}$ Nonetheless, this is occurring in the context of the other institutional and normative shifts towards more control by shareholders over managers, outlined above. Many of these involve more control-oriented mechanisms, which may resonate also with non-US traditions in operating companies. Although seemingly less noted or widely talked about (Kozuka 2003), arm's length mechanisms - more representative of Americanisation generally - do continue to gain strength too in this important stakeholder relationship.

\footnotetext{
${ }^{12}$ On pragmatism and 'creolisation' in globalisation involving Japan, see generally Befu (2003, pp. 16-19). Kubori (2003, pp. 5-6) highlights another important practicality. By June 2006, even Old Type Companies must find at least two outside statutory auditors. Because this creates similar challenges to finding independent directors, he expects then a majority of well-known companies to become New Type Companies.
} 


\section{B. CReditors, ReCession, AND FinANCial Market Deregulation}

A distinctive feature of post-War corporate governance in Japan has been the greater importance of creditors as stakeholders, due to comparatively more use of bank rather than equity finance. Yet this characteristic has been fading over the last two decades, as companies accumulated retained earnings and gradual financial market deregulation permitted them to more readily raise funds through bond issues and so on. Another spate of recent reforms to the Commercial Code is aimed at further boosting equity finance, by giving investors and managers more choices over how to capitalize a new venture and more choices over how to meet the ongoing funding needs of the new business - just as share options and buybacks provide more choices over how to design incentive schemes to ensure its continued efficient operation. The logic behind the reforms is consistent with other government initiatives to shake Japan out of its protracted economic malaise. With news dominated still by bankruptcies and rising unemployment, the government hoped the reforms would spark corporate-led economic growth. The reasoning is that a more flexible toolkit of corporate finance tools should allow efficient, new businesses to replace failing, unproductive industries. More importantly, the greater range of financing options should empower expanding businesses to satisfy more flexibly their ongoing funding needs.

The 151st annual session of the Diet in 2001 enacted a number of changes to allow greater freedom to determine the initial capital structure of a Japanese kabushiki kaisha (joint stock company, the main focus of this chapter). The key amendments, which came into effect on 1 October 2001, include:

- abolishing the requirement that the issue price of shares at the time of incorporation must be a minimum of 50,000 yen;

- removing the prohibition on share splits that caused either (i) the aggregate nominal amount of the issued shares to exceed the stated capital or (ii) the amount of net assets per 
stock to be less than 50,000 yen - moreover, share splits can now be effected by a board decision without a shareholder vote, even if it requires an amendment to the company's articles of incorporation to increase the number of authorized shares;

- abolishing par-value shares, thereby eliminating any differences between par-value shares and no-par shares; and

- introducing the voting unit (tangen-kabu) system, under which a Japanese company may provide in its articles of incorporation that a certain number of its shares constitute one unit, that is, one voting right.

Tanahashi (2002) argues that these amendment removed significant hurdles for fast-growing start-up companies. Prior to the amendments, the minimum share price requirement meant that early start-ups, often without significant net assets, would issue only a few shares. Company growth would cause these shares to represent significant value in the company, making it difficult to raise further funds by granting share options. Further, the post-split net asset requirement meant that share splits were not always possible. A possible stop-gap measure - issuing no-par shares at a nominal value pro-rata among all shareholders - was impractical in post-IPO companies, because it was not realistic to require all shareholders pay even nominal consideration for the newly issued shares. Therefore, abolishing minimum share prices, net asset value requirements for share splits and par-value shares - as well as allowing differential voting rights - has given startup companies greater flexibility in structuring their initial capitalisation to allow for future expansion. 13

Further, under Commercial Code amendments approved on 21 November 2001 and coming into effect on 1 April 2002, corporations are able to streamline the means by which it can

\footnotetext{
${ }^{13}$ More generally on venture business, see for example Sibbitt $1998 \mathrm{~b}$.
} 
obtain ongoing equity financing, especially when multiple infusions of equity are required over a relatively short period of time. This allows for smooth financing of companies, particularly ventures and emerging companies which often cannot secure debt funding from banks. Under the former law, companies often needed to secure a special resolution - at a properly convened general meeting - to access equity finance during periods of high growth. Thus, the so-called ' $4: 1$ rule' restricted the number of shares a company could issue in a given capital increase to four times the number of shares that the company already had outstanding. This meant that pre-IPO companies, seeking multiple infusion of equity financing, would have to go through a long, drawn-out series of issuances, each time convening a general meeting to secure a two-thirds vote to amend the number of authorized shares in its articles of incorporation. Adding to this complexity, the Commercial Code granted pre-emptive rights to shareholders for any new issuance of shares. Once again, a twothirds shareholder vote was required to issue new shares without honouring such pre-emptive rights.

The new provisions simplify the procedures for growing business to acquire as-needed equity funding. Thus, the 4:1 rule no longer applies to closed companies (that is, those companies whose articles of incorporation require director transfers of shares); and shareholders can now authorize the board of a closed company to issue, at its discretion over a one year period, a specified number of new shares to third parties at favourable prices without honouring pre-emptive rights.

In addition, the revised Commercial Code increases the types of shares publically listed companies may issue. These include:

- preferred shares or non-common shares with no voting rights or with limited voting rights;

- tracking shares, where the dividends are not fixed but linked to the performance of a certain segment or subsidiary of the issuing company; 
- protected shares where holders can exercise veto rights in respect of certain company actions; and

- mandatory convertible shares where the shares may be converted into another type of share at the discretion of the issuing company and not the holder.

With these reforms only coming into effect in late 2001 and 2002, it is still too early to tell whether the new provisions are having their desired effect. However, as with the steady uptake in stock option and share buyback schemes mentioned above (Part II.2), there is some evidence that companies are enthusiastically taking advantage of their increased financing powers.

Conversely, already in mid-1997 (before Japan's banking crisis), a survey of managers found that 60 percent expected the role of 'main banks' to decline (Yasui 1999: 12). The relative importance of equity markets in corporate finance will undoubtedly expand in importance in the wake of ongoing economic stagnation and the current severe credit crunch, combined with globalisation and broader financial market deregulation. The latter program was initiated at the end of 1996, but mostly from 1998, due to poor return on capital by Japanese financial institutions throughout the post-War period, and especially a rapid loss of global competitiveness in the 1990s. This 'Big Bang' (or 'Long Bang'!) is now complete, and the legislative and structural reforms are very wide-ranging. 14

As mentioned above (Part II.1), like other stakeholder relationships, the relationship between creditors and managers gives rise to problems of adverse selection (leading to credit going too readily to risky firms) and of moral hazard (monitoring

\footnotetext{
${ }^{14} \mathrm{~A}$ comprehensive time-line is available from the Ministry of Finance, at http://www.mof.go.jp/english/big-bang/ebb33.pdf; see also (Sibbitt 1998a).
} 
problems allowing poor projects by management). Blame for the abrupt decline in the Japanese financial sector over the 1990s lies in part with the Japanese government, particularly the Ministry of Finance (the Bank of Japan having become a more independent policy maker only recently). Yet Japanese financial institutions were also responsible for their own plight, having embarked on a huge spending spree in the late 1980s, which has led to the massive bad debts reported in recent years. Generally, this disaster stems from distortions in evaluating and pricing risk. Specifically, it relates to problems in corporate governance which encouraged financial institutions in Japan to lend (and invest) in risky firms, and then not adequately monitor managers in those firms (Kanaya and Woo 2000).

One solution for these tensions between creditors and managers is to give creditors shares in the companies they lend to. This helps to the extent that shareholders generally can overcome agency problems vis-à-vis managers (on which, therefore, see again Part II.1). In addition, creditors can attempt to monitor managers in two main ways. One, again, involves more arm's length control. The creditor still delegates much control to managers, but may step in to force bankruptcy, thus creating an incentive for managers to pursue creditors' interests (Hoshi 1998: 853). However, forcing bankruptcy must be a credible option, and Japanese bankruptcy law has had various problems which only started to be addressed seriously towards the end of the 1990s (Anderson 2000: 700-24; Anderson 2001; Anderson and Steele 2003). One result has been enactment of a more functional corporate reorganisation regime in 1999. From when the Civil Rehabilitation Law came into effect in April 2000 through to August 2002, 31 reoganisations had been initiated and 16 had been resolved in about six months, compared to an average of two years under the old Corporate Reorganisation Law over the same period (Xu 2003). Further, West (2003a: 25) observes that this regime, which also applied to individuals, was little used by them until amendments were added in 2000 (adding home mortgage exemptions, and so on). But he argues that its more ready availability and uptake since then has helped legitimate 
bankruptcy and reduce its social stigma, even contributing to a decline in consumer debt related suicides. Although less or different stigma may be attached to bankruptcies for companies, this further 'norm shift' prompted by law reform seems likely to underpin increasing use of corporate insolvency options as arm's length control mechanisms by creditors over the managers in firms they lend to.

Alternatively, or in addition, creditors can adopt more controloriented strategies. They can monitor more directly the behaviour of managers, and intervene if necessary in their appointment or replacement. One way in which Japanese banks have been able to directly monitor their lenders' managers, at least within Japan, has been by providing a range of services (such as general business advice or match-making) rather than just loans. Yet that was difficult in overseas lending; and encountered difficulties domestically as Japanese companies themselves became more sophisticated, and competition intensified as a result of accelerating financial markets deregulation (Ouandlous and Philippatos 1999). The latter, combined with the recessionary environment facing Japanese financial institutions in particular, also makes it more difficult to retain the long-term relationship required to be a firm's 'main bank' (Yasui 1999: 12-13). Key aspects were a primary lender which also held shares over lengthy periods, and intervened especially in times of debtor's financial distress by seconding bank managers. As banks become strapped for funds, however, they may call in their loans or simply refuse to lend more; an increase in lender liability claims by debtors was noted already in the mid-1990s (Milhaupt 1996: 49-55). More recently, other cases have been reported in which main banks did not save companies by providing loans, while in other instances they did not bear a disproportionate burden of losses following liquidation. A related phenomenon is a belated 'flight to quality' in lending, perversely exacerbating the present credit crunch. Finally, there is evidence of banks selling off their shareholdings, reportedly after client firms offloaded their stocks in banks, and in the shadow of dangerous declines in the ratio of market over book value $4: 1$ in 1986, but only just over 1:1 in 1998 (Fukao 1999: 6-8)). Unwinding 
shareholdings prevents financial institutions remaining or developing into a main bank, better able to monitor debtor firms, and creates less incentive to send their own managers to debtor firms if in distress (especially as even the big banks have enough problems of their own nowadays!). Reputation as a main bank can unravel quickly, and is difficult to regain (Tsuru 1999: 8).

Such breakdowns become even more likely as more and more foreign financial institutions have taken advantage of deregulation to enter the Japanese market since the late 1990s (Sibbitt 1998). These outsiders are particularly likely not to take over, and certainly not take on, even small shareholdings in debtor firms in such a changing environment. Even if they do, they may refuse to 'take turns', accepting the delegation of other creditor/shareholders to send valuable management resources to help keep debtor firms alive. Their inclination, no doubt often in their short-term interest, may be to enforce their strict legal rights, calling in their security or forcing bankruptcy. After all, lending institutions (and associations) in Japan have long made sure that their strict rights are well protected by contract and commercial practice at the time of lending (Kanda 1998: 940).

Three other factors continue to undermine the main bank system (Milhaupt 2001: 19-21). The first arises from the nationalisation and re-privatisation of the failed Long-Term Credit Bank. The government sold it to a group of foreign investors including Citigroup, giving a 'put option' to return any assets (loans) that decline from book value (as of 1 March 2000) by 20 percent or more within three years. But this is lost if the bank accepts a borrower's request for loan forgiveness. In mid-2000, the reprivatized bank refused to forgive debts owed by Sogo Department Store, forcing it into bankruptcy, going against what has been expected a main bank. More generally, bank failures like this one undercut an implicit guarantee against this given by the Japanese government (Milhaupt and Miller 1997), in exchange for strong institutions supporting weak ones through the main bank system. Finally, the Asian financial crisis and Japan's long recession are 
perceived to have caused a significant shift in beliefs about the benefits of bank-oriented corporate finance and governance.

\section{EMPLOYEES AND THE VICISSITUDES OF THE LABOUR MARKET}

Another often cited aspect of Japanese corporate governance, especially through to the 1980s, is also under threat: the strong influence of employees (for example Miwa 1998). The conventional wisdom has been that Japanese corporate governance was profoundly influenced by the orientation of companies first towards 'people' (ie employees), then 'products' (ie technically excellent goods), then 'profits' (for shareholders). This is contrasted with the German model (fixated first on products, then people, and then profits), and especially the Anglo-American model (first profits, then products, people last!). The importance of employees in Japanese companies has admittedly been strong, at least 'regular' employees in larger corporations (a steadily declining proportion).15 Yet this factor can also be analyzed in terms of agency problems, and how their stakeholding in companies relates to that of other stakeholders. That analysis, together with observed tendencies in the labour market and important legislative amendments, points to further growing pressures on Japanese corporate governance.16

Usually, discussions of relations between employees and managers centre on the latter as 'principals', attempting to hire the former as

\footnotetext{
${ }^{15}$ Lehmann 1997: 96-99. This relative ranking picture accords with some survey evidence included in a book published in 1997 by a Kyoto University economics professor (Tachibanaki 1999: 51). However, the proportion of non-regular employees continues to grow (Abe 2002).

${ }^{16}$ See also Fukao (1999: 21, 23). But see Haley (2002: before note 19), asserting still with very little empirical data on labour market transformations - that Japan will not change its fundamentally 'communitarian' orientation without change in what sees as the most distinctive and central institutional feature of post-War Japan: 'entry level hiring coupled with a central personnel office staffed by senior career manager(s) with full responsibility for the recruitment, training, assignment and promotion of career staff'.
} 
'agents' despite the possibility of adverse selection, and to monitor their delegated activities despite moral hazard ('shirking', due again to imperfect information in the relationship). This can simply be reversed to analyze implications for corporate governance. The problem then becomes how employees, as principals, constrain managers, agents who may prefer to fritter away company funds on themselves. One solution is to give employees shares in the company. However, Employee Share Ownership Programmes (ESOPs) still do not play such a major role in Japanese corporate governance (Hayakawa 1997), and will only constrain managers to the extent that agency problems between shareholders and managers are resolved generally (Part II.2 above). Otherwise, the only realistic alternative is more control-oriented measures. One example is the two-tier board structure for Germany stock companies, in which a supervisory board is partly elected by employees, and then appoints management board members (du Plessis 2004). Japanese corporate law provides no such formal mechanism for employee supervision of managers. Yet control arises in practice especially because most managers in large Japanese companies have been appointed from among existing employees, in a system of life-long employment and promotion based primarily on seniority. Correspondingly, the external labour market has not grown much in recent decades.

Again, the origins of such institutions are unclear. Like several supposedly distinctive features of Japanese law (such as limited numbers of practising lawyers (Haley 1978), the practice of lifelong employment seems to have taken root only quite recently (cf also Foote 1996). Gilson and Roe (1999: 520) observe that 'from World War I through to the end of World War II, worker mobility in external labor markets eroded labor stability when labor was tight, and employees' willingness to fire even senior workers eroded labor stability when labor markets were not tight. Employees tried but failed to build wage and seniority structures to induce workers to stay during labor shortages. Government intervention reduced but failed to stop turnover'. They argue that lifetime employment practices arose in the even more unlikely economic environment shortly after World War II, characterized by extreme labour 
surplus, because of exceptional political events. Rapid unionisation and radical worker activism /strikes and plant takeovers) prompted conservative reactions and a 'deal' establishing a privileged segment of labour (mainly surviving employees) accorded lifetime employment. Thereafter, 'Japan's economic problem was to craft associated institutions that could function effectively given the politically imposed lifetime employment', including restrictions in external labour markets (ibid: 524). Yet nowadays Japan faces a very different political as well as economic environment, with record unemployment (and further 'under-employment'), and institutional changes opening up the possibility again of increasing worker mobility through external labour markets. Gilson and Roe (ibid: 540) also identify several significant 'stress points' in the post-War Japanese system. For instance, it does not cope well during times of dramatic technological change,17 and 'competition' among lifelong employees for promotion in an internal labour market will not work effectively when firms no longer are growing.

Rather similarly, Shishido (2000: 222) points out that labour turnover rates in the 1920s and 1930s were almost the same as those in the US, but the latter jumped in the 1940s and have remained much higher ever since. He argues that the transformation in the US was linked to the Great Depression, and that if the Japanese recession continues there will be an irreversible decline in lifetime employment as a key aspect sustaining the post-War corporate governance system in Japan. More generally, ongoing recession creates a zero-sum situation and heightens conflicts between employees and other stakeholders, notably shareholders. The latter will no longer tolerate employees being treated as de facto residual claimants, for instance earning wage hikes or salary bonuses while dividends remain constant or decline (cf also Ghosn 2003: 17). In parallel, Shishido (ibid: 217)

${ }^{17}$ Including significant developments in IT in the late 1990s, after an admittedly slow start at least compared to the US (Nottage 1998, Ibusuki and Nottage 2002, Jain 2002). 
identifies considerable strengthening of the external labour market and the corporate control (share-) market.

Labour law scholars such as Yamakawa (1999), perhaps due to reliance on more historical data, are more impressed by the enduring quality of the post-War model; but note a number of major challenges to this model. One is precisely the broader political economy environment. The recession plus deregulation create more variability in corporate profitability, a key factor as the credit crunch still facing Japanese financial institutions further encourages companies to turn to stock and bond markets - often global, and more demanding of good corporate and managerial performance. In addition, the service sector continues to grow in importance, bringing the need for (and the possibility of) more flexible working hours (cf also Hanami 1999). Both factors are related to changing demographics in the labour force generally, characterized by more elderly people, women, and part-time workers (Kezuka 2000). This also affects the resilience of lifelong employment as a core concept in the Japanese corporate world. Yamakawa (2001) still concludes that it will remain, albeit with some modifications. Data from various surveys supports such conclusions, although also often confirming a move towards performance-based remuneration.18 However, a problem with most of these surveys is that they question incumbents within firms. To get a better picture of the future of this central aspect of Japan's employment and corporate governance systems, more research should be conducted into what young people want nowadays. Certainly it seems that they are disillusioned with the fact that present employment patterns in Japan are strongly biased towards the incumbent, older generation, especially those in lifelong employment (Genda 1999, 2003).

\footnotetext{
${ }^{18}$ See the three surveys over 1999-2000 summarized in Nottage 2001b; and generally Abe 2002.
} 
In addition, Yamakawa (2001) surveys major changes recently made to an array of labour legislation. These should cement in place or encourage broader transformations in the labour market in Japan, sometimes following changes in norms and/or underlying socio-economic institutions (as with takeovers: Milhaupt 2001) and sometimes rather prompting them (as with consumer bankruptcy reform: West 2003a). These changes include, for instance:19

- 1998 amendments to the Labour Standards Law: allowing longer-term labour contracts; requiring written clarifications of work conditions upon hire, and reasons for termination (a growing source of tension); and divorcing overtime payments from hours worked (indicating more stress on quality of work);

- 1997 amendments to the Equal Employment Opportunity Law (Wolff 2003): now prohibiting discrimination in recruitment, assignment, promotion, as well as in dismissal and retirement; compelling employers to mediation if requested by employees; and addressing problems of sexual harassment (still a frequent source of litigation, since the early 1990s);

- 1995 amendments (in effect from April 1999) to the Child Care Law: extending leave to provide care to elderly family members (Webb 2002);

- 1999 enactment of a Fundamental Law for a Gender-Equal Society (which may encourage affirmative action

\footnotetext{
${ }^{19}$ Further details on these and related changes affecting especially Japan's external labour market are set out in (Nottage and Wolff 2000-3, paras JPN II60$003 \mathrm{ff}$ ) and (Nottage 2001b). Updated information can be found readily in the regular publications freely available from the Japan Institute for Labour Policy and Training (formerly the Japan Institute of Labour, at http://www.jil.go.jp/english/index.html), as well as the extra recent references cited in the text.
} 
programmes, or other broader transformations in women's work: cf generally Miller 2003);

- 1999 amendments to the Working Dispatching Law: abolishing the 'positive list' system of limiting dispatching to specified (professional) job categories, in favour of a 'negative list' system; and putting pressure on companies using such temporary helpers to offer them employment first if the company decide to hire for work done by them (potentially creating a new hybrid category of employees);

- Simultaneous amendments to the Employment Security Law: also changing to a 'negative list' system for private placement of non-temporary workers; clearer licensing for businesses doing this; and replacement of a blanket fee maximum chargeable (which hampered attempts to headhunt and place managers) (West 2003b: 17-20);

- moves to promote pension plans based on 'defined contributions' pension, rather than just 'defined benefits' (which had discouraged voluntary job-switching, because complete vesting was unusual).

In addition to recent changes in the legal environment, and longstanding transformations in political economy broadly related to globalisation described at the start of this Part, globalisation is also beginning to have a more direct effect on the Japanese labour market. In the boom times of the 1980s, many 'guest workers' were brought in for blue-collar work which Japanese were unwilling to touch. Many have stayed on, often illegally. Yet a significant feature of the 1990s has been a slowly growing presence of white-collar employees and managers, even at the highest executive level. This is most noticeable in the financial sector, but it is tied to broader patterns in foreign direct investment, especially increasing Mergers and Acquisitions involving companies from abroad (Milhaupt and West 2001). While it is too early to say what independent effect these developments will have on the labour market in Japan, cumulatively they reinforce the 
changes described above, impacting on the future of corporate governance in Japan.

D. Conflicting Tendencies in Industrial Production AND the STATE?

Thus, applying basic principal-agent theory to analyze three key aspects of Japanese corporate governance suggests that the interests of managers and shareholder have drawn closer together; that severe challenges have emerged for corporate finance centred on main banks; but pressures reshaping employment relations may be less obvious and consolidate only over the longer term. Overall, this amounts to more convergence towards arm's length relations characteristic of Anglo-American corporate governance. Further complicating the picture, however, the notion of opportunism underlying principal-agent theory may not be the only force at work. This become apparent when we look at further stakeholders in the firm.

Another important set of stakeholders, affecting the relations among the others described so far, consists of the firm's outside suppliers and customers. Particularly intriguing are the cooperative relations which have developed among firms, especially in the automobile industry, notably in post-war Japan but later finding root in the US. Some recent studies of industrial organisation have focused on 'learning by monitoring' in this industry (and some others), involving: (i) benchmarking (exacting surveys of current and likely future products and processes) to uncover new general products, (ii) simultaneous engineering (where sub-units responsible for components undertake similar benchmarking, while considering implications for other sub-units, which may lead to redefining the project as a whole), and (iii) systems of strict error detection and correction for the new routines, with further extensive information sharing to respond quickly before consequences become disastrous (Helper, McDuffie and Sabel 2000: 466). The emergence of this paradigm suggests that pervasive patterns of information sharing may entrench norms of cooperation, seen not just as a means of securing 
individual benefits but rather as an end in itself, underpinned by a vision of 'enlarging the pie' rather than trying to obtain a larger slice at the others' expense. History also shows how dramatic changes in conditions may unravel such collaborative relations (as in the US automobile industry over the 1950s-70s), but then build them up again as underlying mechanisms become apparent (as in the 1980s-90s) (ibid: 476-7).

It is not yet clear what has happened to relations among firms in Japan's automobile industry, especially since the late 1990s, when the changes to other aspects of corporate governance described above appeared to find more traction. Despite some notable developments, the economic and social logic underpinning cooperative inter-firm relations may prove resistant in this industry. It is demonstrably more successful, and still holds reserves to draw on, compared for instance to Japan's weak financial sector. Further, although Japan's auto manufacturers are now using e-commerce to unwind keiretsu or preferential relationships with suppliers for standardized products, they seem to be retaining such relationships for more technologically complex parts.20 Relative stasis in such an important production chain would present a tension with the trends towards change identified above (Parts II.1-3), even if the latter relations (mostly within the firm) are more determinative of corporate governance. But a similar tension arguably characterized the US over the 1980s and 1990s, as contracting among firms (at least in some manufacturing and services sectors) became more based on information sharing and learning by monitoring, yet arm's length control and market-based coordination increasingly characterized corporate governance in its narrower sense (Sabel 1996).

The (re-)entrenchment of learning by monitoring mechanisms in the US at the level of industrial production, and their possible resilience in Japan, may encourage the emergence of novel forms

\footnotetext{
${ }^{20}$ Kashiwagi (2001: 3.b.v). See also Farrell \& Findlay (2004: 258-65). Generally, on the ambivalent changes in the industry, see for example Ghosn 2003.
} 
of corporate governance in both countries: 'corporate incubators' for strategic thinking established within firms, performance metrics based on baskets of measures subjected to continuous review and redefinition, and venture capitalists. However, these applications are less well established than in industrial production, and are thought to run more risk of being displaced by more straightforward market-based corporate governance mechanisms (Helper et al 2000: 477-501).

On the other hand, they may also be supported by similar processes of learning by monitoring being played out at other levels implicating two further stakeholders in corporate organisations. The first is individual consumers and their organisations, as opposed to business customers of firms. Traces of the three elements characteristic of 'learning by monitoring' model described above - benchmarking by the person requiring the goods, simultaneous engineering by sub-units involving in production, and careful error detection and reporting - seem at least partially applicable to the relationships that build up to link consumers via retailers to manufacturers. A key premise is proactive and demanding consumers, prepared to voice their needs and complaints, but this is precisely what has emerged quite steadily since World War II and particularly since the 1990s.21 In recent years, this has seemed more to involve a more cynical and confrontational attitude on the part of consumers. However, a new equilibrium may now be close, involving patterns of more pervasive and balanced information sharing that may entrench new norms of cooperation based on mutual respect.

The model is more directly applicable at the level of the state, as a second broader stakeholder in corporate organisations. An important parallel trend in advanced industrialized democracies appears to be 'democratic experimentalism' (Dorf and Sabel 1998), involving: (a) central authorities which 'create a framework for

\footnotetext{
${ }^{21}$ Maclachlan 2002; Nottage and Trezise 2003; Nottage 2004: especially 8-16.
} 
experimentation by defining broad problems, setting provisional standards, pooling measurements of local performance, aiding poor performers to correct their problems, and revising standards and overall goals according to results'; and (b) 'local units doing most of the problem-solving but which are 'accountable to the center, and to their local constituents, who participate in formulating its plans, and judge it both against those goals and in comparison to the performance to the performance of other locales in like circumstances' (Sabel and O'Donnell 2000: 17). Key parameters in experimentation involving the state are again transparency and participation by diverse affected actors, to prompt access to - and effective use of - information to develop collaborative and effective relations. Important trends in this direction in Japan nowadays include:

- sweeping deregulation programmes, although these have tended to get bogged down in detail and bureaucracy (Katz 2002);

- enactment of comprehensive official information disclosure legislation in 1999 (Shultz 2001);

- more engagement with foreigners and foreign models, at some levels (Clark 2000; Takao 2003);

- some legal recognition of previously marginalized ethnic groups (Stewart 2003);

- adroit attempts by other minorities to avoid 'bureaucratic capture' while improving their lot (Nakamura 2001);

- more support for such initiatives through reforms of legislation involving Non-Profit Organisations (Pekkanen 2000); and

- greater opportunities to build on traditions of local autonomy in Japan (Jain 2000). 
These shifts are also underpinned by major reforms underway since 2001 regarding access to justice in Japan, although driven also by business interests (Kitagawa and Nottage 2004). To be sure, such steps towards a more vibrant civil society (Schwartz and Pharr eds, 2003) may have been more faltering even than in some neighbouring countries, like Korea (see eg Ginsburg 2001). Yet significant momentum has been generated in Japan over the last decade, pointing the way towards more sustained polyarchic 'deliberative democracy' there too (cf generally Cohen and Sabel 1997). This adds further contingencies and difficulties in assessing existing and potential changes in Japanese corporate governance, pressuring firms into taking 'corporate social responsibility' more seriously (Iwai and Kobayashi 2003: 12). But these more political dimensions may prove to be the most crucial, despite having been overlooked by most theorists during Japan's lost decade.22 The seeming paralysis of Japanese policy-makers can then be seen in a more positive light. Perhaps it shows important elements of 'democratic experimentalism', with (a) central authorities slowly reorganising key building blocks after extensive analysis of worldwide trends, but (b) leaving it primarily to social-economic subunits (such as major stakeholders in firms including creditors and employees, with their peak associations) to find a new balance and forms of governance combining efficiency with normative acceptability (cf for example West 2001a). However, that more positive assessment turns crucially on whether the Japanese state is and will remain committed to fostering information flows and decentralized participation in decision-making among diverse socio-economic groups.

\section{CONCLUSIONS}

This chapter has outlined a broad conception of corporate governance incorporating a variety of stakeholders both within and outside firms, considering information flows among some of

\footnotetext{
${ }^{22}$ See, however, Fort and Schipani 2000: 865; Ballon and Honda 2000: xviii; and Gilson and Roe 1999.
} 
them. A primary aim has been to assess the extent of change in Japan, particularly towards a 'US' model dominated by shareholder interests and arm's length relationships. Key actors and relationships, and some of the shifts, are depicted in Figure 1 below:

\section{FIGURE 1: CONCENTRIC CIRCLES OF STAKEHOLDER INFLUENCE}

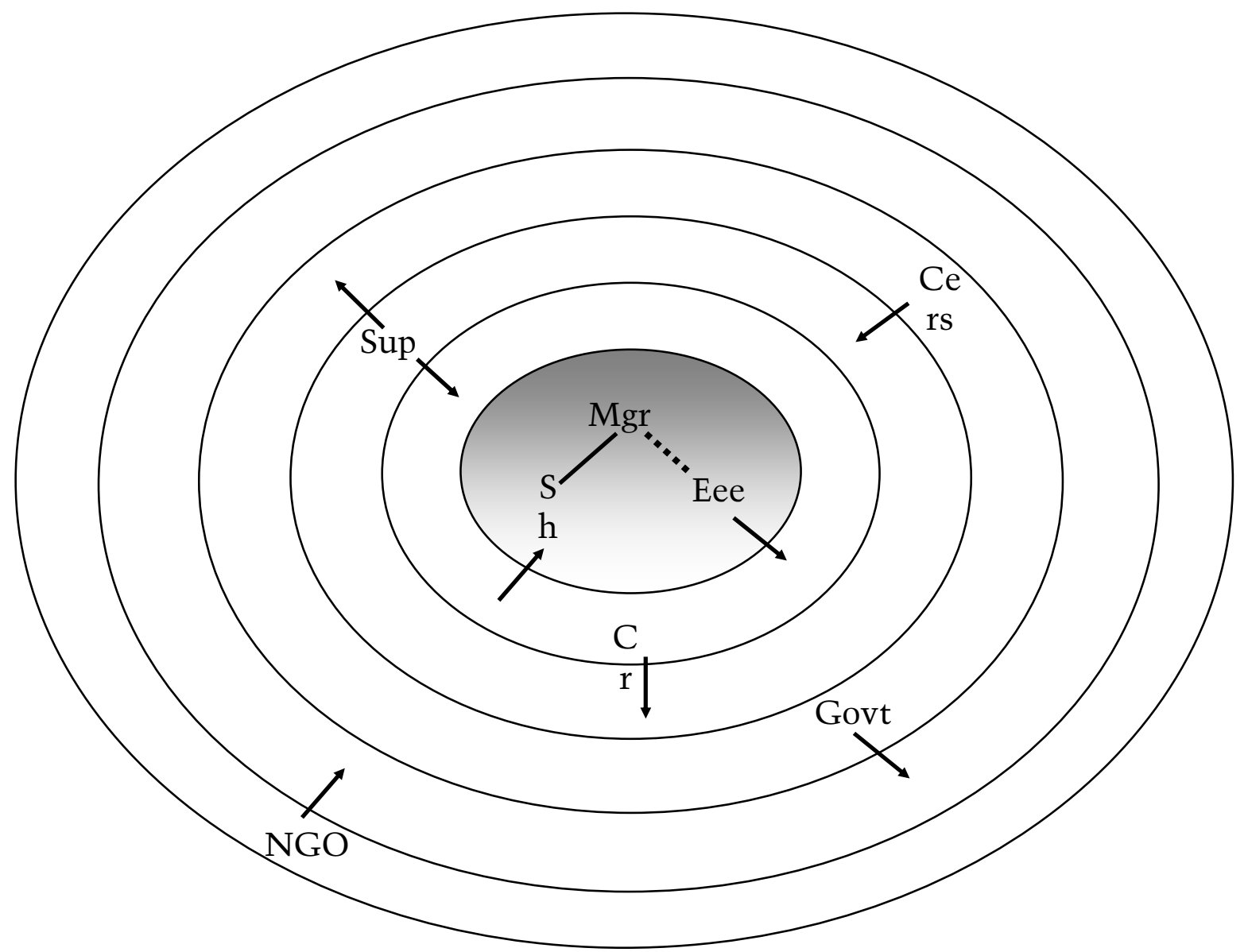

Mgr = Managers

Sh $=$ Shareholders

Eee $=$ Employees

Sup = Suppliers

Cer $=$ Consumers

Govt $=$ State

NGO $=$ Non-Government

Organisations

$\rightarrow \quad=$ Changing Influence 
The darkened core includes the stakeholders which have traditionally been of most concern to substantive corporate law applied to public listed companies. First, shareholders, and their relationships with managers, have been of key doctrinal significance. Part II.1 showed how this has grown in practical importance particularly since the 1990s, strongly pulling shareholders towards the centre of Japan's brave new world of corporate governance. Although the expanding relative importance of shareholders is partly achieved through more direct controls (such as derivative suits), more arm's length control is also increasing. Second, the stakeholder position of employees has only recently been highlighted in corporate governance discussions focused on Anglo-American-Australian law and practice, particularly in the aftermath of large corporate insolvencies (Hill and Yablon 2003). But its significance has long been apparent in Japan, at least since the 1950s, especially in the form of life-long employment and other de facto constraints on managers of large companies. Despite considerable durability of the latter model, however, distinctions and arm's length relationships are emerging between employees and managers. The role of employees, as stakeholders independently monitoring managers, is therefore declining (Part II.3).23 Thirdly, creditors have also found little formal recognition within substantive corporate law, yet their stakeholder role became clear in post-War Japan through the main bank system. The latter's decline and corresponding moves to encourage further emphasis on equity financing, underpinned by financial markets deregulation, may even be propelling creditors

\footnotetext{
${ }^{23}$ Proposed whistle-blowing legislation may offset this tendency, despite problems with draft legislation submitted to Cabinet ('A Whistle-Blower Bill Has Insufficient Safeguards', International Herald Tribune (Herald Asahi), 24 January 2004). However, whistle-blowing may actually reinforces the distinction between employees and managers, and it helps other stakeholders (notably shareholders), so law reform and practice in this area constitutes another facet of a transfigured corporate governance regime evolving now in Japan.
} 
outside the realm of core stakeholders in Japanese corporate governance (Part II.2).

Fourthly, suppliers may be drawn into or nearer the core, to the extent that long-term collaborative relationships based on information-sharing through 'learning through monitoring' can be maintained or expanded. Their situation is ambivalent, however, because many supply relationships are becoming much more arm's length, due to deregulation and ongoing recession. Simply 'exiting' is easier in such relationships, so they may result in diminished potential for mutual monitoring between suppliers and buyers. By contrast, consumers and their interest groups represent a fifth set of stakeholders which has become more actively engaged in firms, highlighting a greater role in corporate governance. That tendency is supported by broader shifts, finally, involving the state and its citizens. The Japanese government has blatant interests in corporate performance - notably economic recovery and restoration of the tax base - which make it important as a direct stakeholder. It is also significant more indirectly, by intensifying deregulation and other structural reforms which have already prompted major realignments in other stakeholder relationships within Japanese corporate governance. Another more subtle role for the state in Japan nowadays may be to reinforce variants of the 'learning by monitoring' model, based on a more optimistic and 'embedded' view of human relationships (Swedberg and Granovetter eds, 2001) than that underpinning agency theory analyses of information flows (Part II.4).

Thus, as we move out beyond the core of Japan's corporate governance world depicted above, the picture becomes increasingly complicated. The extent of change in the relationships affecting more peripheral stakeholders, and what concerns and philosophies are driving those relationships, become more difficult to explain or predict. By contrast, change is clearer at the core, even allowing for the tendency of comparative lawyers to see more transformations or convergence when comparing lawrelated phenomena more narrowly (Nottage 2001a). There are indeed considerable tendencies towards convergence on a 
shareholder-oriented model of corporate governance, at the expense of an employee-oriented one and especially a bankoriented model.

Yet, the control mechanisms are not just more arm's length ones, fitting best with US socio-economic ideology. Straightforward 'Americanisation' is also undermined by some ongoing attraction of German (and now EU) traditions, or even AngloCommonwealth variants of the 'US model'. Perhaps most importantly, as we progress beyond the core concerns of corporate lawyers, the complex and shifting role of the state reminds us that much will depend on political contingencies. On the one hand, Japan's recent 'elective corporate governance reform' show a tendency towards 'reformist conservatism' consistent with other recent law-related reforms, notably legal education (Nottage 2001c). A sense emerges of a wide-ranging crisis and that something must be done, but the change ends up superimposing a new model on top of an old one (rather than abandoning the latter) with more or less incentives to adopt the new model. The incentives have been more pervasive in legal education reform, but weaker or more disparate so far for corporate organisation, depending for example on the degree to which firms and their sectors are open to global competitive pressures (Schaede and Grimes 2003). On the other hand, there seem likely to be limits to generalisations about Japan's new political environment and policy-making processes (cf Grimes and Schaede 2003). Broader promotion of 'learning by monitoring' within and by Japan's polity may also reinforce growing value pluralism (Moehwald 2000), and it may be possible to track the latter's complex bedding down in general and specific policy-making processes impacting on corporate governance and commercial regulation more generally (see generally Huntington and Harrison 2000). However, ultimately or in some areas, the interactions may become so complex that they may be understood more parsimoniously by applying something like 'chaos theory', which focuses on how small regular iterations can result in large and often counterintuitive changes (cf generally for example Williams and Arrigo 2001). 
What is clear already, from the broad-based analyses of changes of corporate governance outlined in this chapter, is that corporate law in Japan is playing an integral role in this process (see also for example Kanda and Milhaupt 2003). Indeed, changes to corporate law - and areas of law impacting on stakeholders in a broader sense than other than those focused on by corporate law itself seem to have been quite dramatic and effective. This is ironic from the perspective of the US, where corporate practices and expectations changed well before corporate law was transfigured, and prominent commentators expect that this phenomenon is a powerful one elsewhere (Hansmann and Kraakman 2001). Other commentators seem to have underestimated the potential, at least in Japan, for law to prompt ongoing socio-economic change in Japan (for example Milhaupt 2003: 29-31; cf generally Aoki 2003). Yet law's precise role remains intriguing - sometimes cementing or following social norms or institutional changes; sometimes prompting considerable transformations. 


\section{BIBLIOGRAPHY}

Abe, M. (2002) 'Corporate Governance Structure and Employment Adjustment in Japan: An Empirical Analysis Using Corporate Finance Data', Industrial Relations 41, pp. 683-702.

Ahmadjian, C. (2003) 'Changing Japanese Corporate Governance', in U. Schaede and W. W. Grimes (eds) Japan's Managed Globalization: Adapting to the Twenty-First Century, Armonk, N.Y.: M.E. Sharpe, pp. $215-42$.

Anderson, K. (2000) 'The Cross-Border Insolvency Paradigm: A Defense of the Modified Universal Approach Considering the Japanese Experience', University of Pennsylvania Journal of International Economic Law 21(4), pp. 679-779.

Anderson, K. (2001) 'Small Businesses Reorganizations: An Examination of Japan's Civil Rehabilitation Act Considering U.S. Policy Implications and Foreign Creditors' Practical Interests', American Bankruptcy Law Journal 75(3), pp. 355-407.

Anderson, K. and S. Steele (2003) 'Insolvency', in V. Taylor (ed.) Japanese Business Law Guide, Sydney: CCH Australia (looseleaf).

Aoki, M. (2003) 'Institutional Complementarities between Organizational Architecture and Corporate Governance', Paper presented at the RIETI conference, "Corporate Governance from an International Perspective: Diversity or Convergence", Tokyo, 8-9 January 2003, http://www.rieti.go.jp/en/events/03010801/pdf/Aoki.pdf.

Aronson, B. (2003) 'Reconsidering the Importance of Law in Japanese Corporate Governance: Evidence from the Daiwa Bank Shareholder Derivative Case', Cornell International Law Journal 36, pp. 11-57.

Ballon, R. and K. Honda (2000) Stakeholding: The Japanese Bottom Line, Tokyo: The Japan Times.

Befu, H. (2003) 'Globalization Theory from the Bottom Up: Japan's Contribution', Japanese Studies 23, pp. 3-22.

Berle, A. A. and G. C. Means (1991) The Modern Corporation and Private Property, New Brunswick, N.J., U.S.A.: Transaction Publishers. 
Black, B. and B. Cheffins (2003) 'Outside Director Liability across Countries', Stanford Law \& Economics Research Paper Series 266, http://ssrn.com/abstract=438321.

Callen, T. and J. Ostry (eds) (2003) Japan's Lost Decade: Policies for Economic Revival, Washington DC: International Monetary Fund.

Cheffins, B. (2002) 'Comparative Corporate Governance and the Australian Experience: A Research Agenda', in I. Ramsay (ed.) Key Developments in Corporate Law and Trusts Law: Essays in Honour of Professor Harold Ford, Chatswood: LexisNexis Butterworths, pp. 651-64.

Cioffi, J. (2000) 'State of the Art [Review Essay]', American Journal of Comparative Law 48, pp. 501.

Clark, G. (2000) 'Why Is Japan Turning to Foreigners for Help?' Japan Echo 27/2, pp. 123.

Clarke, F. L., G. W. Dean, et al. (2003) Corporate Collapse: Accounting, Regulatory and Ethical Failure, Cambridge: Cambridge University Press.

Coffee, J. (1999) 'The Future as History: The Prospects for Global Convergence in Corporate Governance and Its Implications', Northwestern University Law Review 93, pp. 641.

Cohen, J. and C. Sabel (1997) 'Directly Deliberative Polyarchy', European Law Journal 5, pp. 123.

Dore, R. P. (2000) Stock Market Capitalism, Welfare Capitalism: Japan and Germany Versus the Anglo-Saxons, Oxford [UK] ; New York: Oxford University Press.

Dorf, M. and C. Sabel (1998) 'A Constitution of Democratic Experimentalism', Columbia Law Review 98, pp. 267.

Du Plessis, J. J. (2004) 'Reflections on Some Recent Corporate Governance Reforms in Germany: A Transformation of the German Aktienrecht?' Deakin Law Review 8(2), pp. 389-404.

Elder, M. (2003) 'Meti and Industrial Policy in Japan: Change and Continuity', in U. Schaede and W. W. Grimes (eds) Japan's Managed 
Globalization: Adapting to the Twenty-First Century, Armonk, N.Y.: M.E. Sharpe, pp. 159-90.

Farrell, R. and C. Findlay (2004) 'Automobiles: An Industry Study', in P. Drysdale (ed.) The New Economy in East Asia and the Pacific, London: Routledge Curzon, pp. 257-72.

Feldman, E. A. (2001) 'The Landscape of Japanese Tobacco Policy: Law, Smoking and Social Change', American Journal of Comparative Law 49(4), pp. 679-706.

Foote, D. H. (1996) 'Judicial Creation of Norms in Japanese Labor Law: Activism in the Service of--Stability?' UCLA Law Review 43, pp. 635709.

Fort, T. L. and C. A. Schipani (2000) 'Corporate Governance in a Global Environment: The Search for the Best of All Worlds', Vanderbilt Journal of Transnational Law 33, pp. 829.

Fukao, M. (1999) 'Japanese Financial Instability and Weaknesses in Corporate Governance Structure', Paper presented at the OECD conference on "Corporate Governance in Asia: A Comparative Perspective, Seoul, 3-5 March 1999.

Fukuyama, F. (1992) The End of History and the Last Man, New York/Toronto: Free Press.

Fukuyama, F. (1996) Trust: The Social Virtues and the Creation of Prosperity, London: Penguin.

Genda, Y. (2000) 'Youth Employment and Parasite Singles', Japan Labour Law Bulletin 39(3), http://www.jil.go.jp/bulletin/year/2000/vol3903/05.htm.

Genda, Y. (2003) 'Dangers Facing Businessmen in Their 20s and 30s Who Work for Large Companies', Japan Labor Bulletin 42(2), pp. 7-11.

Ghosn, C. (2003) 'Japanese-Style Management and Nissan's Revival', Japan Echo 30(5), pp. 15-8. 
Gilson, R. and M. Roe (1999) 'Lifetime Employment: Labor Peace and the Evolution of Japanese Corporate Governance', Columbia Law Review 99, pp. 508.

Ginsburg, T. (2001) 'Dismantling the "Developmental State"? Administrative Procedure Reform in Japan and Korea', American Journal of Comparative Law 49(4), pp. 585-625.

Grimes, W. W. and U. Schaede (2003) 'Japanes Policy Making in a World of Constraints', in U. Schaede and W. W. Grimes (eds) Japan's Managed Globalization: Adapting to the Twenty-First Century, Armonk, N.Y.: M.E. Sharpe, pp. 17-46.

Haley, J. (1978) 'The Myth of the Reluctant Litigant', Journal of Japanese Studies 4, pp. 359.

Haley, J. (2002) 'Law in Japan 2002: A Turning Point?' Washington University Working Paper, http://law.wustl.edu/Academics/Faculty/Workingpapers/TurningPoint.p df.

Hanami, T. (1999) 'Japan', in R. Blanpain and M. Biagi (eds) NonStandard Work and Industrial Relations, The Hague: Kluwer, pp. 109.

Hansmann, H. and R. Kraakman (2001) 'The End of History for Corporate Law', Georgetown Law Journal 89, pp. 439-68.

Hayakawa, M. (1997) 'Shareholders in Japan: Attitudes, Conduct, Legal Rights and Their Enforcement', in H. Baum (ed.) Japan: Economic Success and Legal System, Berlin: de Gruyter, pp. 251.

Helper, S., J. P. MacDuffie, et al. (2000) 'Pragmatic Collaborations: Advancing Knowledge While Controlling Opportunism', Industrial and Corporate Change 9(3), pp. 443.

Hill, J. and C. Yablon (2003) 'Corporate Governance and Executive Remuneration: Rediscovering Managerial Positional Conflict', Vanderbilt Law and Economics Research Paper 03-02, http://ssrn.com/abstract $=375240$.

Iwai, K. and Y. Kobayashi (2003) 'Assessing the State of the Japanese Company', Japan Echo 30(5), pp. 9-14. 
Jain, P. (2000) 'Japan's Local Governance at a Crossroads: The Third Wave of Reform', ANU Pacific Economic Papers 306.

Jain, P. (2002) 'The Catch-up State: E-Government in Japan', Japanese Studies 22, pp. 237-55.

Kanaya, A. and D. Woo (2000) 'The Japanese Banking Crisis of the 1990s: Sources and Lessons', IMF Working Paper WP/00/7 January 2000, http://www.imf.org/external/pubs/ft/wp/2000/wp0007.pdf.

Kanda, H. (1998) 'Comparative Corporate Governance - Country Report: Japan', in K. Hopt et.al. (eds) Comparative Corporate Governance: State of the Art and Emerging Research, Oxford: Clarendon Press, pp. 921.

Kanda, H. and C. Milhaupt (2003) 'Re-Examining Legal Transplants: The Director's Fiduciary Duty in Japanese Corporate Law', Columbia Law and Economics Working Paper 219, http://ssrn.com/abstract=391821.

Kaplan, S. and J. M. Ramseyer (1996) 'Those Japanese with Their Disdain for Shareholders - Another Fable for Academy', Washington University Law Quarterly 32, pp. 403.

Kashiwagi, N. (2001). 'I Can't Turn You Loose: The Termination of Distributors and Agents in Japan'. Paper presented at the conference, "Change Continuity, and Context: Japanese Law in the Twenty-First Century, Ann Arbor.

Kashiwagi, N. (2003) 'A View of Recent Trends in Japanese Corporate Governance', Paper presented at the 18th Biennial Conference of Lawasia, Session 3, Tokyo, 1-5 September 2003.

Kelemen, R. D. and E. C. Sibbitt (2002) 'The Americanization of Japanese Law $^{\prime}$, University of Pennsylvania Journal of International Economic Law 23, pp. 269.

Kester, W. C. (1996) 'American and Japanese Corporate Governance: Convergence to Best Practice', in S. Burger and R. Dore (eds), Ithaca, London: Cornell University Press, pp. 107.

Kitagawa, T. and L. Nottage (2004) 'Globalization of Japanese Corporations and the Development of Corporate Legal Departments: 
Problems and Prospects', in G. Chin and W. Alford (eds) From "Litigation Cudgels" to "Doctors for People's Social Lives"? The Changing Place of Lawyers in East Asia, Cambridge, Mass.: Harvard East Asian Legal Studies Program (distributed by Harvard University Press), pp. forthcoming.

Kobayashi, I. (2003) 'Relational Contracts in Japan: Reformation of Contract Practice under the Unique Corporate Governance Structure', Asian Law (Legal Scholarship Network), http://ssrn.com/abstract=479921.

Kozuka, S. (2003) 'The Use of Stock Options as Defensive Measures', Zeitschrift fuer Japanisches Recht / Journal of Japanese Law 8(15), pp. $135-41$.

Kubori, H. (2003) 'Iinkai to Secchi Kaisha' and Corporate Governance in Japan', Paper presented at the 18th Biennial Conference of Lawasia, Session 3, Tokyo, 1-5 September 2003.

Mattei, U. (2003) 'A Theory of Imperial Law: A Study on US Hegemony and the Latin Resistance', Indiana Journal of Global Legal Studies 10, pp. 383-448.

Milhaupt, C. (2002) 'On the (Fleeting) Existence of the Main Bank System and Other Japanese Economic Institutions', Law and Social Inquiry 27, pp. 425.

Milhaupt, C. J. (2001) 'Creative Norm Destruction: The Evolution of Nonlegal Rules in Japanese Corporate Governance', University of Pennsylvania Law Review 149(6), pp. 2083-129.

Milhaupt, C. J. (2003) 'A Lost Decade for Japanese Corporate Governance Reform?: What's Changed, What Hasn't, and Why', Columbia Law School Center for Law and Economic Studies Working Paper 234, pp. 136.

Miller, R. L. (2003) 'The Quiet Revolution: Japanese Women Working around the Law', Harvard Women's Law Journal 26, pp. 163-215.

Miwa, Y. and J. M. Ramseyer (2002) 'The Legislative Dynamic: Evidence from the Deregulation of Financial Services in Japan', Harvard Law and Economics Discussion Paper 373, http://ssrn.com/abstract=324601. 
Moehwald, U. (2000) 'Trends in Value Change in Contemporary Japan', in J. S. Eades (ed.) Globalization and Social Change in Contemporary Japan, Melbourne: Trans Pacific Press, pp. 55.

Moerke, A. (2003) 'Rumble in the Boardroom? The Change of Japanese Corporate Governance Schemes', Zeitschrift fuer Japanisches Recht / Journal of Japanese Law 8(15), pp. 142-60.

Morgan, C. A. (2001) 'Demographic Crisis in Japan: Why Japan Might Open Its Doors to Foreign Home Health-Care Aides', Pacific Rim Law \& Policy Journal 10(3), pp. 749-79.

Nakamura, K. (2001). 'Manipulating the System from Within: Deaf Civil Society Organizations in Japan'. Paper presented at the conference "Change Continuity, and Context: Japanese Law in the Twenty-First Century, Ann Arbor.

Nottage, L. (2001a) 'Convergence, Divergence and the Middle Way in Harmonising or Unifying Private Law', E.U.I. Working Paper in Law No. 2001/1, http://www.iue.it/LAW/res/nottage/EUIWorkingPaper4.pdf.

Nottage, L. (2001) 'Japanese Corporate Governance at a Crossroads: Variation in "Varieties of Capitalism", The North Carolina Journal of International Law \& Commercial Regulation 27(2), pp. 255-99.

Nottage, L. (2001c) 'Reformist Conservatism and Failures of Imagination in Japanese Legal Education', Asian Pacific Law and Policy Journal 2, pp. 28-65 (also at http://www.hawaii.edu/aplpj/2/16.html).

Nottage, L. (2003) 'Japan Inc Goes Global: Elective Corporate Governance Reform', CCH Asiawatch 57, pp. 6-8.

Nottage, L. (2004) Product Safety and Liability Law in Japan: From Minamata to Mad Cows, London: RoutledgeCurzon.

Nottage, L. and M. Trezise (2003) 'Mad Cows and Japanese Consumers', Australian Product Liability Reporter 14(9), pp. 125.

Nottage, L. and L. Wolff (2000-3) 'Japan', in Doing Business in Asia, Singapore: CCH Pte Ltd (looseleaf). 
Okuda, H. (2003) 'A Business Leader on the Offensive', Japan Echo 30(2), pp. 47-50.

Osano, H. and K. Hori (2002) 'Financial Relations between Banks and Firms: New Evidence from Japanese Data', Kyoto Institute of Economic Research Discussion Paper 546, http://ssrn.com/abstract=357943.

O'Sullivan, M. (2000) 'Corporate Governance and Globalization', Annals of the American Academy of Political and Social Science 570, pp. 153.

Ouandlous, A. and G. Philippatos (1999) 'The Effect of Japanese Financial Liberalization on Keiretsu, the Main Bank System, and Japanese Corporate Financing: Evidence for 1972-1992', Legal Scholarship Network, http://ssrn.com/abstract=250374.

Pekkanen, R. (2000) 'Japan's New Politics: The Case of the NPO Law', Journal of Japanese Studies 26(1), pp. 111.

Perez, A. (2002) 'International Antitrust at the Crossroads: The End of Antitrust History or the Clash of Competition Policy Civilizations?" Law and Policy in International Business 33, pp. 527-54.

Puchniak, D. W. (2003) 'The 2002 Reform of the Management of Large Corporations in Japan: A Race to Somewhere?' Australian Journal of Asian Law 5(1), pp. 42-76.

Reich, P. (2001) 'T Boone Pickens and Corporate Governance in Japan: A Retrospective View of Three Sides of the Story and Recent Developments', Law in Japan 27, pp. 27-36.

Rodatz, P. (2003) 'Bemerkungen Zur Struktur Der Japanischen Unternehmungsleitung Nach Den Juengsten Gesellschaftrechtlichen Reformen', Zeitschrift fuer Japanisches Recht / Journal of Japanese Law 8(15), pp. 161-9.

Sabel, C. (1996), 'Ungoverned Production: An American View of the Novel Universalism of Japanese Production Methods and Their Awkward Fit with Current Forms of Corporate Governance', Paper presented to the Institute of Fiscal and Monetary Policy conference on "Socio-economic systems for the 21st Century", Tokyo, http://www2.law.columbia.edu/sabel/papers/Japan.html. 
Sabel, C. and R. O’Donnell (2000). Democratic Experimentalism: What to Do About Wicked Problems after Whitehall (and What Scotland May Just Possibly Already Be Doing). Paper presented to the OECD conference on "Devolution and Globalisation: Implications for Local Decision-makers", http://www2.law.columbia.edu/sabel/papers/glasPO.html.

Glasgow,

Sarra, J. and M. Nakahigashi (2002) 'Balancing Social and Corporate Culture in the Global Economy: The Evolution of Japanese Corporate Culture and Norms', Law and Policy 24, pp. 299-354.

Schaede, U. (2000) Cooperative Capitalism: Self-Regulation, Trade Association, and the Antimonopoly Law in Japan, Oxford: Oxford University Press.

Schaede, U. (2003) 'Industry Rules: From Deregulation to SelfRegulation', in U. Schaede and W. W. Grimes (eds) Japan's Managed Globalization: Adapting to the Twenty-First Century, Armonk, N.Y.: M.E. Sharpe, pp. 191-214.

Schaede, U. and W. W. Grimes (2003) 'Introduction: The Emergence of Permeable Insulation', in U. Schaede and W. W. Grimes (eds) Japan's Managed Globalization: Adapting to the Twenty-First Century, Armonk, N.Y.: M.E. Sharpe, pp. 3-16.

Schultz, D. M. (2001) 'Japan's Information Disclosure Law: Why a Law Full of Loopholes Is Better Than No Law at All', Law in Japan 27, pp. 128-69.

Schwartz, F. J. and S. J. Pharr (eds) (2003) The State of Civil Society in Japan, Cambridge, U.K. ; New York: Cambridge University Press.

Senechal, M. (2003) 'Reforming the Japanese Commercial Code: A Step toward an American-Style Executive Officer System in Japan?' Pacific Rim Law \& Policy Journal 12, pp. 535-59.

Shibata, H. (2002) 'Wage and Performance Appraisal Systems in Flux: A Japan-United States Comparison', Industrial Relations 41, pp. 629-52.

Shishido, Z. (1990) 'Problems of the Closely Held Corporation: A Comparative Study of the Japanese and American Legal Systems and a 
Critique of the Japanese Tentative Draft on Close Corporations', American Journal of Comparative Law 38, pp. 337-72.

Shishido, Z. (2000) 'Japanese Corporate Governance: The Hidden Problems of Corporate Law and Their Solutions', Delaware Journal of Corporate Law 25(2), pp. 189-233.

Shishido, Z. (2001) 'Reform in Japanese Corporate Law and Corporate Governance: Current Changes in Historical Perspective', American Journal of Comparative Law 49(4), pp. 653-77.

Sibbitt, E. C. (1998a) 'A Brave New World for M\&A of Financial Institutions in Japan: Big Bang Financial Deregulation and the New Environment for Corporate Combinations of Financial Institutions', University of Pennsylvania Journal of International Economic Law 19(4), pp. 965-1027.

Sibbitt, E. C. (1998b) 'Law, Venture Capital, and Entrepreneurism in Japan: A Microeconomic Perspective on the Impact of Law on the Generation and Financing of Venture Businesses', Connecticut Journal of International Law 13(1), pp. 61-106.

Stewart, A. D. (2003) 'Kayano v. Hokkaido Expropriation Committee Revisited: Recognition of Ryukyuans as a Cultural Minority under the International Covenant on Civil and Political Rights, an Alternative Paradigm for Okinawan Demilitarization', Asian Pacific Law and Policy Journal 4(2), http://www.hawaii.edu/aplpi/pdfs/v4-stewart.pdf.

Swedberg, R. and M. S. Granovetter (eds) (2001) The Sociology of Economic Life, Boulder, Colo.; Oxford: Westview Press.

Takao, Y. (2003) 'Foreigners' Rights in Japan: Beneficiaries to Participants', Asian Review 43, pp. 523.

Tanahashi, H. (2002) 'Japan: A Better Environment for Start-Ups and Venture Capital', International Financial Law Review 2002(65), pp. 65.

Tokumoto, M. (2001) 'The Role of Japanese Courts in Hostile Takeovers', Law in Japan 27, pp. 1-16. 
Von Nessen, P. (1999) 'The Americanization of Australian Corporate

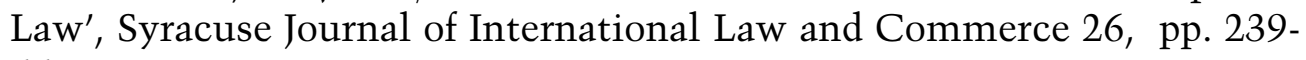
66.

Von Nessen, P. (2003) 'Corporate Governance in Australia: Converging with International Developments', Australian Journal of Corporate Law 15 , pp. 189-224.

Watanabe, T. (2004) 'Tax Consequences of Stock Options in Japanese

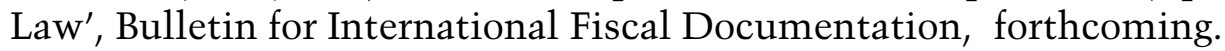

Webb, P. (2002) 'Time to Share the Burden: Long Term Care Insurance and the Japanese Family', Japanese Studies 22, pp. 113-29.

West, M. D. (1997) 'Legal Rules and Social Norms in Japan's Secret World of Sumo', Journal of Legal Studies 26, pp. 165-201.

West, M. D. (2001a) 'The Puzzling Divergence of Corporate Law: Evidence and Explanations from Japan and the United States', University of Pennsylvania Law Review 150(2), pp. 527-601.

West, M. D. (2001b) 'Why Shareholders Sue: The Evidence from Japan', Journal of Legal Studies 30(2 (pt1)), pp. 351-82.

West, M. D. (2003a) 'Dying to Get out of Debt: Consumer Insolvency Law and Suicide in Japan', Michigan Law and Economics Research Paper 03-15, http://ssrn.com/abstract=479844.

West, M. D. (2003b) 'Employment Market Institutions and Japanese Working Hours', Michigan Law and Economics Research Paper 03-016, http://ssrn.com/abstract=479882.

Williams, C. and B. Arrigo (2001) Law, Psychology and Justice: Chaos Theory and the New (Dis)Order, Albany NY: State University of New York Press.

Williamson, O. (1996) The Mechanisms of Governance, Oxford: Oxford University Press.

Wolff, L. (2003) 'Beyond Japan Inc: Facilitating Flexibility in Equity Financing', CCH Asiawatch 58, pp. 9-11. 
Wolff, L. (2003) 'Japanese Women and the "New" Administrative State', in J. Amyx and P. Drysdale (eds) Japanese Governance: Beyond Japan Inc, Sydney: Routledge, pp. 157-70.

Xu, P. (2003) 'Bankruptcy Resolution in Japan: Corporate Reorganization vs Civil Rehabilitation', Paper presented at the RIETI conference, "Corporate Governance from an International Perspective: Diversity or Convergence", $\quad$ Tokyo, 8-9 January 2003, http://www.rieti.go.jp/en/events/03010801/pdf/Xu.pdf.

Yamakawa, R. (1999) 'The Silence of Stockholders: Japanese Labor Law from the Viewpoint of Corporate Governance', Japan Labor Bulletin 38(11), http://www.jil.go.jp/bulletin/year/1999/vol38-11/04.htm.

Yamakawa, R. (2001) 'Labor Law Reform in Japan: A Response to Recent Socio-Economic Changes', American Journal of Comparative Law 49(4), pp. 627-51.

Yasui, T. (1999), 'Corporate Governance in Japan', Paper presented at the OECD conference on "Corporate Governance in Asia: A Comparative Perspective", Seoul.

Yoshimatsu, H. (2000) Internationalization, Corporate Preferences and Commercial Policy in Japan, Houndmills; New York: Macmillan Press; St. Martin's Press. 